\title{
EXPLORING THE PROBLEMS FACED BY PRACTITIONERS OF MICRO, SMALL, AND MEDIUM ENTERPRISES (MSMEs) IN YOGYAKARTA
}

\author{
Tony Wijaya", Nurhadi, Andreas M. Kuncoro \\ Faculty of Economics, Yogyakarta State University, Indonesia \\ *Corresponding author; Email: drtonyw12@gmail.com
}

\begin{abstract}
The research purpose is to explore the obstacles which faced by business practitioners of MSMEs to develop business. It is a relativism research by digging information based on their experience perspective. The research informants are the business practitioners of MSMEs in Yogyakarta who understand the conditions, problems and directly involved in MSMEs management. The primary data is obtained by in depth interview and analyzed by narrative technique. The problems faced in running the business are external factors such as situation and condition, location, business permit, competition and business information and internal factors such as management of the business, the less skilled workers, product/ production and supplier control, marketing and capital.
\end{abstract}

Keywords: Business obstacles, micro small and medium enterprise, owner.

\section{Introduction}

At a time when the economy in Indonesia is faced multi dimensional economic problems and the large scale business condition is not being able to maintain its existence, meanwhile micro, small, medium enterprises (MSMEs) still exist (Wijaya, 2008). It is reasonable since micro, small, medium enterprises have the prospects to be developed also it has a different characteristic compared to large scale business. The difference can be seen from the scale of business, a number of workers, and production capacity of MSMEs which have a toughness and resilience in maintaining continuity of business ( $\mathrm{Ri}$ yanti, 2003). Besides having advantages over large scale efforts, micro, small, medium enterprises (MSMEs) have an important role in the economy. Micro, small, medium enterprises contribute to the stability of the national economy for both all the countries that are developing or developed countries (Myslimi \& Kacani, 2016). Indonesia Central Bureau of Statistic (BPS) data shows that the amount of Gross Domestic Product that created by MSMEs throughout 2013 reaches Rp 1,536,918.80 Billion (BPS, 2016). The number of business units of MSMEs reached 42.4 million, with the number the worker working in this sector recorded 79 million workers. The business unit of the economic sector that absorbs the most workers is from small companies compared to big companies (Riyanti, 2003). This shows that micro, small and medium enterprises have the potential to be developed in Indonesia since it able to restore the national economy. Small businesses and household enterprises that are not incorporated and found in all sectors of the economy are business that provides many fields of business without requiring a certain level of education or special skills. The existence of MSMEs become one of the alternatives to overcome poverty and create employment (Chiware \& Dick, 2007) since it has a strong resilience when Indonesia experiencing economic crisis (Niode, 2009).

The development of an economic system in the small and medium business will encourage the growth of the economy which based on entrepreneurship and is also able to encourage the growth of new businesses (Wijaya, 2008). The spread of small and medium enterprises in rural areas are able to encourage the equitable distribution of employment opportunities. The monetary crisis that occurred in 1997 slow pace of economic recovery in the following year has led to the collapse of the national economy. As a result of these events, there was a change in the fundamental paradigm of the national economy. Tambunan (2002) has pointed out a number of problems related to errors in neglecting the development of an economy that prioritizes small and medium sized enterprises. The existence of such cases as the slow economic recovery in total until now is associated with a faulty strategy by paying more attention to the Big Enterprises (UB) and neglecting MSMEs.

MSMEs has advantages compared to another business scale, by Macro MSMEs also plays an important role in the national economy. MSMEs has a strong influence on the economy of all countries (Ladzani \& Vuuren, 2002). MSMEs contribute to the 
stability of the national economy of developing countries as well as developed countries (Myslimi \& Kacani, 2016). MSMEs is the most dynamic business in all countries and have a key role in achieving social economic goals (Ghobadian \& Gallear, 1996).

Zimmerer and Scarborough (2005) contend that out of 25 million businesses in America, about 99\% of them come from small scale companies that employ less than 100 people percompany. Small companies have created two-third to three-quarters of new jobs in the US economy. Small companies have contributed $51 \%$ of the country's private sector's Gross Domestic Product (GDP).

The ASEAN Economic Community (AEC) is both a challenge and an opportunity for MSMEs. MSMEs will exist, only if the business practitioners able to compete and realize that AEC is an opportunity. Some internal aspects such as capital, management and external aspects such as economy, fuel price increase, UMP and many more are obstacle for MSMEs to developing, besides the other problem of MSMEs in Indonesia is individual managed business management by involving family and close relatives, according to the report, the business by notarial deed is only $1.7 \%$ (Tedjasuksmana, 2014). In addition to the low access of small industries to formal credit institutions, the limitations and difficulties of procurement of export oriented raw materials, the lack of competence in human resources (Tedjasuksmana, 2014) is also the reason or obstacles for MSMEs to grow.

Previous research conducted by Musaroh and Wijaya (2015) in exploring the profiles of Micro, Small and Medium Enterprises in the area of Yogyakarta, showed there are a lot of issues that are complex and diverse. Many business practitioners of MSMEs stated that they have never received assistance or guidance in a various program implemented by the government, the assistance provided was not in accordance with the problem faced. The main focus of this research is the problems experienced by MSMEs. The research conducted is an attempt to explore the basic constraints faced by MSMEs, particularly in the development, expected these constraints can be a consideration for the related institutions to assist MSMEs business practitioners in facing the existing problems.

\section{The Role of Micro, Small and Medium Enterprises}

In the era of regional autonomy, each region is encouraged to take advantage of local resources to improve the competitiveness of products produced by the region, both in the domestic and international mar- kets with the paradigm of thing locally but action globally. Since MSMEs is the pillar of economy sector, therefore in the future MSMEs group should pay attention to several things such as: (1) high competitiveness, (2) democracy, (3) to improve efficiency, it is necessary to develop in knowledge and technology, (4) decentralized and spread evenly on each region, (5) become an activator motor of national economic development (Musaroh \& Wijaya, 2015). Indonesia economic foundation will be concentrated on the small and medium business. Related to the distribution of income and the development of MSMEs, it will be able to encourage a fairer equitable distribution of income rate. In fact it seen from the experience that exists for 30 years, with more focus on the development of the industry and large scale business without giving priority to the development of MSMEs have proved the occurrence of failure in building Indonesia's economy from global crisis, this is proved by the existence of MSMEs when Indonesia experienced a crisis in the year 1998 (Riyanti, 2003; Irjayanti \& Azis, 2012). Therefore, the Central Government, as well as the region, will turn to the type of small and medium sized business (Musaroh \& Wijaya, 2015). In accordance with the policy direction of the GBHN instructed that national economic development is closely related to the empowerment of the economic sector based on small and medium business.

The role of MSMEs are: (1) as field of work that is able to absorb many worker and the potential to reduce unemployment and poorness, (2) contribute to the increment of the Product Domestic Bruto (PDB)/ Gross Domestic Product (GDP) and economic growth, and (3) contribute to an increase in export while also potentially to expand exports and investment (Haetubun, 2006). Parallel with the increase in the number of MSMEs, the overall numbers of workers absorbed will also increase. For example in America from 25 million business around 99\% comes from small scale business and has created two per three until three quarters of the new jobs in the economy of the United States. Small business is contributing $51 \%$ of gross domestic product (GDP) of the country's private sector (Zimmerer \& Scarborough, 2005).

\section{Problems Encountered in Micro Small, Medium Enterprises}

Various problems arose and faced by MSMEs business practitioner, of which the main ones are market access, access limitation of raw materials, access to capital and access to training in order to improve the skills of the MSMEs perpetrators. The preliminary 
result that has been conducted by Musaroh and Wijaya (2015) in exploring the profile of micro, small and medium enterprises in the area of Yogyakarta gives an overview of much MSMEs business practitioner experienced very complex and varied problems. Based on the survey result by Musaroh and Wijaya (2015) in some MSMEs in Yogyakarta, 87\% from 117 business practitioners of MSMEs expect help and development of the government in accordance to the problem faced by MSMEs. The appropriate solution begins and is sourced from accurate, details and comprehensive data about the primary necessity of the MSMEs development, such as the individual MSMEs perpetrator, the number of MSMEs, type of business, capital used, existing markets, operational and administration during this running, the desired market prospects, as well as other problems and the solution or activities taken in resolving the problem. One of the problems related to the development of MSMEs is the limited number of human resources in the adoption of information technology. A problem encountered and simultaneously become MSMEs weakness is the lack of access to information, especially market information (Ishak, 2005). The limited access to market information that should be obtainable through information technology is the obstacle in the marketing product, which results in low level of market orientation and weak competitiveness at the global level. Information has an important role in the decision making a process for small, medium sized business (Mutula \& Brakel, 2006).

Several previous research has revealed that the main obstacles face by MSMEs are information, functional, financial, human resources, technology, marketing infrastructure and the external environment, as well as support from government and business development service. According to Dasanayaka, Kankanamge and Sardana (2011) and Trianni and Cagno (2012), obstacles related information with the accessibility of MSMEs in obtaining information, while expanding the business, no information about the market opportunities, technologies change is seen as another barrier to innovation (Kamalian et al., 2011). Information about the company's external environment, such as market opportunities, technological changes, and government policy support make the business sector more competitive (Guijarro, Garcia, \& Auken, 2009).

Some research also explains the existence of other barriers, Okpara and Kabongo (2009). Okpara (2011) indicates that issues such as lack of management and infrastructure experience are major obstacles to small business development, most owners has no management experience, insufficient training and skills in operating the business. The lack of management training and experience bring negative consequences and is the cause of the underdevelopment of a business entity.

The lack of skilled worker causes difficulties for the business unit to do the innovation process (Kamalian, Rashki and Arbabi (2011). According to Saini and Budhwar (2008), Hessels and Parker (2013), most of the MSMEs does not have training system and lack of formalization of human resources management. Access to finance is an important determinant in all countries, as it affects the creation of new business and the expansion of existing business (Krasiqi, 2007). Commercial banks that are the main source of finance is not willing to give loans to small business because these business units are often not able to provide collateral as a warranty and was considered MSMEs has a high level of uncertainty (Mutalemwa, 2009; Irwin \& Scott, 2010; Okpara, 2011; Hyz, 2011). The high capital cost is other burden in terms of financing of MSMEs. A research conducted by Krasiqi (2007) provides evidence from Slovenia that financial costs and credit insurance payment are the main obstacles to the development of MSMEs. According to Ajlouni (2006), access to finance is one of the common problems faced by all MSMEs in Jordania. Saixing, Xie, Tam and Wan (2009) found that marketing capabilities play a most important role in improving the performance of the company and it also becomes basic obstacles for business practitioners. On the research of Moy and Luk (2003) about the barriers to the growth of MSMEs in Hongkong proposes that the obstacles of the business due to insufficient knowledge of marketing, product performance and the lack of competitive pressure awareness. According to Bourletidis (2013), MSMEs in the manufacturing sector has its disadvantages limitation to access the basic materials (supply) compared with larger companies. According to Dasanayaka et al. (2011), the problem of infrastructure see sub-section of roads and transportation facilities, electrical, communications, facilities and location issues are obstacles in the development of MSMEs. External environment companies such as global competition, government policy, and economic uncertainty become barriers to the growth of MSMEs (Guijarro et al., 2009).

\section{Research Method}

The paradigm in this research is qualitative. Viewed from the perspective of the phenomenon, this research based on naturalist with information based 
on the perspective of the subject experiences. The subject of this research is the owner of MSMEs in Yogyakarta. The data used in this study is the primary data obtained from the owner itself about the constraints in the development of MSMEs. Data collected in 2016, using depth interview method. The technique of data analysis in this research is an explorative narrative that is searching information based on an experience of the owner related to the problems in the development of MSMEs.

\section{The Result of the Research and Discussion}

This research identifies the problem faced by MSMEs owners, based on data collection obtained by 26 informants, MSMEs owners spread across Yogyakarta. Data were collected through interview which aims to obtain information on a matter of constraints and suggestions for the government or the expectations of business owners. Prior to the core information search, researchers first identify the characteristics of the business such as the type of business, capital, and length of business long with business experience.

\section{The Characteristic of Business}

Several characteristics of MSMEs in Yogyakarta are as follows:

a. Type of Business

The types of business studied are very widely, from service groups, manufacturing, and commerce. The type of business in this research belongs to manufacturing groups such as garment/ convection, souvenirs, statue, stamp; service groups such as machine maintenance, salons, restaurant, catering and commerce group such as grocery, photocopying, shoe stores, clothing stores and educational robots. Type of business of the MSMEs is shown on Table 1.

Table 1

Type of Business

\begin{tabular}{lc}
\hline Type of Business & Amount \\
\hline Garment/convection & 3 \\
Souvenir & 2 \\
Statue & 2 \\
Stamp & 2 \\
Machine maintenance & 1 \\
Salon & 2 \\
Restaurant & 3 \\
Catering & 2 \\
Grocery & 3 \\
Photocopy & 2 \\
Shoe store & 2 \\
Clothing store & 1 \\
Educational robot & 1 \\
\hline Total & 26 \\
\hline
\end{tabular}

b. Source of The Capital

Based on the survey result found that the origin of MSMEs capital from internal and external. The capital of MSMEs originating from the internal capital that is private equity, family or relatives, while external capital comes from trade associations, shared contributions, Program of Entrepreneur Student (PMW) loans, and government grants. Most of the capital comes from internal private funds. Source of capital that comes from personal funds shows still need funding or assistance from the external stimulant. Characteristics of MSMEs based on the source of capital are shown on Table 2.

Table 2

Source of the Capital

\begin{tabular}{lc}
\hline Source of the capital & Amount \\
\hline Private funds & 12 \\
Family / Relatives & 4 \\
Trade Associations & 3 \\
Shared Contributions & 3 \\
PMW Loan & 2 \\
Government Grants & 2 \\
\hline Total & 26 \\
\hline
\end{tabular}

c. The Years of Business

The years of business which is run by the owner of MSMEs varies from one year to 20 years. The characteristics of the years of a business show that most businesses are still new and some already survived for 20 years. Characteristics of MSMEs based on its age are shown on Table 3.

Table 3

The Years of Business

\begin{tabular}{cc}
\hline Years & Amount \\
\hline $1-5$ & 12 \\
$5.1-10$ & 6 \\
$10.1-15$ & 4 \\
$15.1-20$ & 4 \\
\hline Total & 26 \\
\hline
\end{tabular}

d. Business Experience

Based on the experience from the MSMEs owner, most of the business is built from the beginning or business directly from the owner, but there is one business was built for the second time. Characteristics of MSMEs based on the experience of business are shown on Table 4. 
Table 4

Business Experience

\begin{tabular}{lc}
\hline Building a business & Amount \\
\hline First time & 25 \\
Second time & 1 \\
\hline Total & 26 \\
\hline
\end{tabular}

\section{Obstacles and Suggestion from the Micro, Small, Medium Enterprises Owner}

From the interview, several problems and also the expectation of MSMEs owner are found.

a. The Obstacles of External factor

The interview results with business owner A, B and $\mathrm{M}$ (the owner's initials) related to the situation and condition problems are as follows:

During the holiday season, consumers are less since the consumers mostly are students (A)

......... During rainy days consumer are less (B)

Depends on the season (M)

Based on the interview result with the owner was found that the condition and situation factor affecting sales turnover, especially for food service business (food shop and catering) and souvenir. According to the owner, situation and condition on vacation periods and the weather is an obstacle, since most of the consumers are students.

The interview result with business owners I, H, G and $\mathrm{F}$ (the owner's initials) related to the location obstacles or business location is as follows:

......... Business location is less spacious (I)

......... Remote location - far from business activity $(\mathrm{H})$

......... Business location is not strategic to be known $(\mathrm{G})$

......... Location is difficult to reach $(\mathrm{F})$

Business location is an issue for the business owner. The business owner needs a strategic location and spacious area to be able to introduce its business to the consumer. This issue is the part of marketing effort, with the present locations owner finds difficulties in marketing their products. The location is part of the problem of MSMEs development, according to Dasanayaka et al. (2011), the issue of infrastructures such as roads and transportation facilities, power facilities, communications and location issues are an obstacle to the development of MSMEs.

The interview result with business owners $\mathrm{H}$ and $G$ (the owner's initials) related to the permission issue is as follows:

......... License/permission must be fully equipped to cooperate with Indonesian State Owned Enterprises (BUMN) or government $(\mathrm{H})$
Permission problems $(\mathrm{G})$

The next problem is related to the permit issue. According to the business owner they must complete the licensing, as the requirement to collaboration with BUMN or other institutions. These results are in accordance with the research conducted by Musaroh and Wijaya (2015) discovered the existence of several obstacles for MSMEs related to the permissions. The Owner of MSMEs feel difficulties in licensing arrangements also in preparing all requirement documents related to the terms of collaboration.

The interview result with business owners I, F and $G$ (the owner's initials) related to the business competition issue is as follows:

......... Competition with large scale business (I)

........ Difficult in marketing, narrow market share with the same rivals $(F)$

...Medium and above segments (slightly expensive), many competitors in batik motive and the price is cheap $(\mathrm{G})$

Owners of MSMEs feel that competition or business competition became obstacles for MSMEs to develop. The information required in order for the business unit is able to compete. Guijarro et al. (2009) mentioned that the information on the external environment on the company, such as market opportunity, technological change and government policy make the business sector more competitive.

The interview result with business owners I, G, H and D (the owner's initials) related to the obstacles in business information and limitations in information access including the adoption of information technology as follows:

......... Require information to met consumer needs (I)

Sometimes difficult to get information related to market demand $(\mathrm{G})$

......... Require competent human resources to access business chain information to collaborate $(\mathrm{H})$

......... Require information technology to get business information (D)

Lack of business information, limitations in accessing information and competence of human resources in the use of information technology is an obstacle for the business owner in running the business. The business owner needs to know the business information about customer demand and market demand related to the product that is produced. The management information system is not available yet, make the business owner it is difficult to meet market demands and search for 
business relations. These problems are similar to those found by Dasanayaka et al. (2011), Trianni and Cagno (2012), which find information associated with MSMEs accessibility to the information needed while expanding the business. Have no information about market opportunities, technological change is seen as another barrier to innovation (Kamalian et al., 2011).

b. The Obstacle of Internal Factors

The interview result with business owners $\mathrm{C}, \mathrm{F}$, $\mathrm{M}, \mathrm{I}, \mathrm{L}, \mathrm{J}, \mathrm{D}, \mathrm{G}$, and $\mathrm{E}$ (the owner's initials) related to internal problems as follows:

........ Obstacles in the company management (C) .........There is no accounting to separated finance $(\mathrm{F})$

......... The company management only assis by student (M)

......... Need worker who can work and experience (I)

......... Small capital (L)

.......... Many buyers are indebted and hard to collect (J)

.......... Still dependent on supplier (D)

......... Production is still dependent on partner $(\mathrm{G})$

........ Raw materials shipment is not on time (E)

Internal factor obstacles in running a business are classified as:

a) The problem in business management, such as the absence of accounting records, difficult to manage capital, since there is no separation between personal and business money, b) Lack of skilled workers in managing business, c) Control on product or production and supplier, d) Marketing problem, e) Capital problem refers to small capital, f) The problem on the production is raw material. The price of raw materials are too expensive since they are not buying directly from the supplier, the problem of delay in access to raw materials is also a barrier in production activities. Other MSMEs problems are integrated with the findings of Tedjasuksmana (2015), which is more to individual business management by involves family also close relatives and weak competence in human resources. This is also confirmed by Okpara and Kabongo (2009) and Okpara (2011), suggesting that issues such as a lack of management experience, and a lack of infrastructure are the major barrier to small business development, most of the business owner has no management experience. Material limitations become an issue. This is accordance with Borletidis (2013) opinion, that MSMEs has a weakness to access the supply base. Related to the marketing issues also in accordance with the findings of Saixing, et al. (2009) that the company's marketing ability is also become a basic constraint for business practitioners.

The following are quote of advice from business owner G, H, I, J and L (the owner's initial)

Support from the government both material and easiness on arrangement of NPWP and SIUP and other licensing $(\mathrm{G})$

..........Expectation for the government to help introduce the product $(\mathrm{H})$

Simplify requirements: to facilitate collaboration with State Owned Enterprises, etc., make it less and simple business requirements, by reviewing the list of licensing requirements, such as business permit from the ministry of commerce and industry, but other licenses such as notaries, domicile and NPWP are enough (I)

..........Expectation for the government to participate in raising the business $(\mathrm{J})$

......... The government is expected to provide additional capital for small business (L)

The government is expected to increase its potential $(\mathrm{M})$

..The government is expected not to do any eviction without provide relocation area (A, D)

The addition of capital from the government for business development (B)

......... Assisting in terms of capital and promotion $(\mathrm{E})$

......... Support and facilities business establishment $(\mathrm{C})$

There are some suggestions or expectations from business owners to the government. Business owner expects the support from government and easiness in running the business. Based on the interview results, it is known that business owners expect material support such as easiness of handle permit/assisting, marketing/promotion, increasing business potential and business relocating. Based on the characteristics of capital origin, since most of it is own capital or personal funds, and then there is a problem for business development. Limitations of resource in marketing the product also become part of the problem in running the business. Therefore, business owners expect the support or assistance of business product promotion.

\section{Conclusion and Implications}

Based on the research result it was concluded that in the process of running a business, MSMEs 
owners face the obstacles of external factors when sales are situational and depends on the conditions, such as holiday season, weather and seasonal rains. Other problems are the location of the business less profitable it is not convenient for marketing as well as hard to reach by consumers. Business stall is limited, difficult process in arranging business licences or completeness requirement permission letter to collaborate with institute such as BUMN and business competition that demanding information including business opportunities. In addition to external factors, there is also internal factors where the MSMEs owner find problems in managing the business finance, as there is no accounting record to separating personal and business finance, making it difficult in capital management, this is caused by the management of the business are familial and traditional. Worker available is less skilled in managing business affect the product capacity, there is no product control/production and supplier, availability of raw materials affect the quantity and quality of production and also difficulty in marketing as well as the capital.

Below is some suggestion from researchers related to the research results: On the external factor which become obstacles for MSMEs, owners need to understand the process of business permit arrangement. The Government should give a nonmaterial support by providing easiness to letters/ permission arrangement or provide mentoring in the arrangement of the business license/collaboration. The Government also expected to provide assistance for relation if there is any eviction of business land. The business owner needs to adopt information technology in order to obtain business information since the ability of MSMEs to survive in the increasingly competitive global environment depends on the capacity of the information owned (Mutula \& Brakel, 2013).

Related to the internal factor, is necessary to the owner of MSMEs to provide a good administrative system in financial management, provide training for the worker to develop skills, adopt a system of quality control of products and have a good relationship with suppliers. The Government needs to provide support in material such as the capital as well as marketing/promotion through varieties marketing programs and help to connect supplier with business owners.

\section{References}

Ajlouni, K. (2006). The financing problems of small and medium-sized manufacturing enterprises in Jordan. Durham University. Unpublished PhD.

Bourletidis, K. (2013). The strategic management of market information to SMEs during economic crisis. Procedia-Social and Behavioural Sciences, 73, 598-606.

Chiware, E. R.T. \& Dick, A. L. (2007). The use of ICTs in Namibia's SME sector to access business information services. The Electronic Library, 26(2) 145-157.

Dasanayaka, S., Kankanamge, R., \& Sardana, G. (2011). Identification of barriers for development of the Srilanka small and medium scale furniture and wooden products manufacturing enterprises. Euro Asia Journal of Management, 21(40), 69-101.

Ghobadian, A. \& Gallear, D. (1996). Total quality management in SMEs. Omega: International Journal of Science, 24(1), 83-106.

Guijarro, A., Garcia, M., \& Auken, H. (2009). Barriers to innovation among Spanish manufacturing SMEs. Journal of Small Business Management, 47(4), 465-488.

Heatubun, A. B. (2006). Potensi jumlah usaha kecil dan menengah dalam peranannya menstimulasi perekonomian. Jurnal Organisasi dan Manajemen, 4, 34-45.

Hessels, J. \& Parker, S. (2013). Constraints, internationalization and growth: A cross-country analysis of European SMEs. Journal of World Business, 48(1), 137-148.

Hidayat. (1998). Rangkuman diskusi usaha kecil menengah: Tantangan dan alternatif jalan keluar Asian foundation \& yayasan Indonesia forum.

Hyz, A. B. (2011). Small and Medium Enterprises (SMEs) in Greece - Barriers in access to banking services. An empirical investigation. International Journal of Business and Social Science, 2(2), 161-165.

Irjayanti, M. \& Azis, A. M. (2012). Barriers factors and potential solutions for Indonesian SMEs. Procedia Economics and Finance, 4, 3-12.

Irwin, D. \& Scott, J. (2010). Barriers faced by SMEs in raising bank finance. International Journal of Entrepreneurial Behaviour \& Research, 16(3), 245-259.

Ishak, E. (2005). Peranan informasi bagi kemajuan UKM. Artikel Kedaulatan Rakyat: Yogyakarta.

Kamalian, A., Rashki, M., \& Arbabi, M. (2011). Barriers to innovation among Iranian SMEs. Asian Journal of Business Management, 3(2), 79-90.

Krasiqi, B. (2007). Barriers to entrepreneurship and SME growth in transition: The case of Kosova. Journal of Developmental Entrepreneurship, 12(1), 71-94.

Ladzani, W. M. \& Vuuren, V. W. (2002). Entrepreneurship training for emerging SMEs in South 
Africa. Journal of Small Business Management, 40(2).

Moy, J. \& Luk, V. (2003). The life cycle model as a framework for understanding barriers to SME growth in Hongkong. Asia Pacific Business Review, 10(2), 199-220.

Musaroh \& Wijaya, T. (2015). Studi eksplorasi profil usaha mikro kecil dan menengah klasifikasi kerajinan di YOGYAKARTA. Laporan Penelitian Pusat Studi Pendampingan MSMEs LPPM UNY: Yogyakarta.

Mutalemwa, D. (2009). Barriers to SMEs development in the manufacturing sector: Evidence from Tanzania. African Journal of Business and Economic Research, 4(2), 93-111.

Mutula, K. S. \& Brakel, P. V. (2013). E-readiness of SMEs in the ICT sector in Botswana with respect to information access. The Electronic Library, 24(3), 402-417.

Myslimi, K. \& Kacani, K. (2016). Impact of SMEs in economic growth in Albania. European Journal of Sustainable Development, 5(3), 151-158.

Niode, I. Y. (2009). Sektor MSMEs di Indonesia: Profil, masalah, dan strategi pemberdayaan. Jurnal Kajian Ekonomi dan Bisnis OIKOSNOMOS, 2(1).

Okpara, J. (2011). Factors constraining the growth and survival of SMEs in Nigeria implications for poverty alleviation. Management Research Review, 34(2), 156-171.

Okpara, J. \& Kabongo, J. (2009). An empirical evaluation of barriers hindering the growth of Small and Medium Sized Enterprises (SMEs) in a developing economy. African Journal of Business and Economic Research, 4(1), 7-21.
Riyanti, B. P. D. (2003). Kewirausahaan dari sudut pandang psikologi kepribadian. Grasindo: Jakarta.

Saini, D. \& Budhwar, P. (2008). Managing the human resource in Indian SMEs: The role of indigenous realities. Journal of World Business, 43(4), 417-434.

Saixing, Z., Xie, X. M., Tam, C. M., \& Wan, T. W. (2009). Relationships between business factors and performance in internationalization: An empirical study in China. Management Decision, 47(2), 308-329.

Tambunan, M. (2002). Strategi industrialisasi berbasis usaha kecil dan menengah: Sebuah rekonstruksi pada masa pemulihan dan pasca krisis ekonomi. Orasi Ilmiah Guru Besar Ilmu Ekonomi Pertanian dan Sumberdaya pada Fakultas Pertanian Institut Pertanian Bogor, 19 Oktober 2002, Bogor.

Tedjasuksmana, B. (2014). Potret MSMEs Indonesia menghadapi masyarakat ekonomi ASEAN 2015. Proceedings the $7^{\text {th }}$ NCFB and Doctoral Colloqium 2014. ISSN: 1978-6522, 189-202.

Trianni, A. \& Cagno, E. (2012). Dealing with barriers to energy efficiency and SMEs: Some empirical evidences. Energy, 37(1), 494-504.

Wijaya, T. (2008). Kajian model empiris perilaku berwirausaha UKM YOGYAKARTA dan Jawa Tengah. Jurnal Manajemen dan Kewirausahaan, 10(2), 93-104.

Zimmerer, T. F. \& Scarborough, N. M. (2005). Essentials of entrepreneurship and small business management. Terjemahan. PT Indeks: Jakarta. Retrieved from www.kompas.com/ business/news/0007/25/24.http://www.MSMEsyogya.com/. 